\title{
Improvement of mechanical properties of bio-concrete using Enterococcus faecalis and Bacillus cereus
}

\author{
Abdullah Faisal Alshalif ${ }^{1^{\dagger}}$, Mohd Irwan $\mathrm{Juki}^{{ }^{+}}$, Norzila Othman ${ }^{2}$, Adel Ali Al-Gheethi ${ }^{2}$, \\ Faisal Sheikh Khalid ${ }^{1}$ \\ ${ }^{1}$ Jamilus Research Centre for Sustainable Construction (JRC), Faculty of Civil and Environmental Engineering, Universiti Tun Hussein Onn Malaysia, \\ 86400, Parit Raja, Johor, Malaysia \\ ${ }^{2}$ Micro-Pollutant Research Centre (MPRC), Faculty of Civil and Environmental Engineering, University Tun Hussein Onn Malaysia, 86400, Parit Raja, \\ Johor, Malaysia
}

\section{ABSTRACT}

The present study aimed to investigate the potential of Enterococcus faecalis (E. faecalis) and Bacillus cereus (B. cereus) in improving the properties of bio-concrete. E. faecalis and B. cereus strains were obtained from fresh urine and an acid mire water at cell concentration of $1.16 \times 10^{12}$ and $1.3 \times 10^{12}$ cells $\mathrm{mL}^{-1}$, respectively. The bacterial strains were inoculated in a liquid medium into the concrete with 1,3 and $5 \%$ as replacement of water cement ratio $(w / c)$. The ability of E. faecalis and B. cereus cells to accumulate the calcite and the decrement of pores size within bio-concrete was confirmed by SEM and EDX analysis. The results revealed that E. faecalis exhibited high efficiency for increasing of compressive and splitting tensile strength than B. cereus ( 23 vs. $14.2 \%$, and 13 vs. $8.5 \%$, respectively). These findings indicated that E. faecalis is more applicable in the bio-concrete due to its ability to enhance strength development and reduce water penetration.

Keywords: Bacteria, Compressive strength, EDX, SEM, Splitting tensile strength, Water penetrations

\section{Introduction}

Due to technological advancement, several types of concrete are in existence such as conventional concrete, fly ash concrete, biomass concrete, fibre concrete, geopolymer concrete and bio-concrete. The bio-concrete has received more attention by the researchers in the recent years due to its high quality in terms of self-healing process resulting improvements of bio-concrete mechanical properties specially compressive strength [1, 2]. These properties represent the main criteria in the generation of concrete. The porosities rely on the porous material used in concrete whereas the pore structure of porous material is characterized by pore size, surface roughness, volume fraction and pore connectivity [3]. Other factors included compaction, water cement ratio, type of materials and aggregate size as well as the hydration and chemical, changes which are associated with the aggressive environment [4]. The increasing of pores in the concrete leads to cause an increment of concrete permeability, which may affect concrete properties specially strength due to ingress of water and gasses [5-7].

The utilization of bacteria to fill up the concrete pores or cracks by self-healing process has been reported by authors in the literature $[8,9]$, The technique is used in order to accelerate the precipitation of calcium carbonate $\left(\mathrm{CaCO}_{3}\right)$ on the bacterial cell wall to increase the compressive and splitting tensile strength as well as reduction in water penetration [8-13]. The bacteria increase the formation of $\mathrm{CaCO}_{3}$ layer as a function for diffusing $\mathrm{CO}_{2(\mathrm{~g})}$ through the wet concrete and production of $\mathrm{HCO}_{3}{ }_{(\mathrm{aq})}$ as an intermediate product. Moreover, the bacterial strain which, has the ability to produce urease enzyme acting as catalyst to produce $\mathrm{CO}_{2}$ and $\mathrm{NH}_{3}$, resulting increase $\mathrm{pH}$ in the surrounding bacteria cells and induce the precipitation of $\mathrm{Ca}^{2+}$ and $\mathrm{CO}_{3}^{2-}$ as $\mathrm{CaCO}_{3}[14]$.

$$
\mathrm{Ca}^{2+}+\text { cell } \rightarrow \text { cell }-\mathrm{Ca}^{2+}
$$

This is an Open Access article distributed under the terms of the Creative Commons Attribution Non-Commercial License (http://creativecommons.org/licenses/by-nc/3.0/) which permits unrestricted non-commercial use, distribution, and reproduction in any medium, provided the original work is properly cited.

Copyright (c) 2019 Korean Society of Environmental Engineers
Received August 21, 2018 Accepted December 31, 2018

${ }^{\dagger}$ Corresponding author

Email: faisalalshalif@gmail.com, irwan@uthm.edu.my Tel:+60-193663061, +60-197758186 Fax: +60-74536588 ORCID: 0000-0001-5882-0472 (A. F. Alshalif) 


$$
\begin{gathered}
\mathrm{Cl}^{-}+\mathrm{HCO}_{3}^{-}+\mathrm{NH}_{3} \rightarrow \mathrm{NH}_{4} \mathrm{Cl}+\mathrm{CO}_{3}^{2-} \\
\mathrm{Cell}-\mathrm{Ca}^{2+}+\mathrm{CO}_{3}^{2-} \rightarrow \mathrm{Cell}-\mathrm{CaCO}_{3} \downarrow
\end{gathered}
$$

The novel properties of bacterial cell surface possession of different functional group enable the bacteria to adsorb $\mathrm{Ca}^{2+}$ ions, which are available with high concentrations in the concrete. The $\mathrm{CO}_{3}{ }^{2-}$ (aq) is generated from $\mathrm{HCO}_{3}^{-}$(aq) in the presence of water and then react with $\mathrm{Ca}^{2+}$ ions adsorbed on the bacterial cell wall to form a complex Cell- $\mathrm{CaCO}_{3}[15,16]$. The mechanism would confidently help to improve concrete durability and contribute to prolong concrete structure life with self-repair technic [17-19]. Over the last decade, the utilization of bio-concrete technology has emerged as viable, sustainable and reproducible solution to address the engineering, geotechnical and environmental issues. However, most of the researchers have been focused on the adaptation of microbial induced $\mathrm{CaCO}_{3}$ precipitation for modification and improvement of constructional materials such as concrete and mortar. Moreover, concrete is susceptible to formation of cracks which in role contribute on reduce the sustainability performance, serviceability and lifespan of the structure. Therefore, bacteria added to different types of concrete to enhance the concrete properties [10, 20].

According to Siddique et al. [17], the addition of $S$. pasteurii bacteria into fly ash concrete enhanced the durability and strength through self-healing process as well as reduced the porosity of concrete, which is associated with the reduction the ingress of moisture. Therefore, the inoculation of bacteria into the concrete might be an alternative technology for acids, chlorides and sulphates, which reduce the strength and sustainability of concrete. However, the selections of bacterial species represent the bottleneck in the bio-concrete potent bacteria. Some of bacteria have been used in the bio-conctrete included Bacillus cereus (B. cereus), B. pasteurii, Pseudomonas aeruginosa, Shewanella sp., which have the ability to precipitate calcium carbonate $\mathrm{CaCO}_{3}[10,19-22]$. However, it has been reported that these bacteria have some deficiency to be applied in the bio-concrete including their potential to survive and grow in concrete environment due to the extreme $\mathrm{pH}$ and salts conditions [22]. This gap offers an opportunity for the researcher to find more applicable bacterial strains. In refereeing to the property of concrete, the bacterial strain used in the bio-concrete should have the potential to grow and have high activity within the concrete.

In the present study, the ability of Enterococcus faecalis (E. faecalis) to increase the compressive strength, splitting tensile strength and reduce the water penetration was investigated in comparison to $B$. cereus, which has been reported in the literature and was used as a control [21]. Moreover, the potential of $E$. faecalis was enhanced by the adaption process. The mechanism in which $E$. faecalis improve the property of bio-concrete was explained based on the analyses of bio-concrete by scanning electron microscope (SEM) and energy dispersive X-ray EDX.

\section{Materials and Methods}

\subsection{Bacterial Strains}

Two bacterial strains were investigated in the present work, namely
E. faecalis (KC113205.1) and B. cereus (KF788142.1). E. faecalis was obtained from fresh urine, while $B$. cereus was recovered from an acid mire water located at Sunga Pelepah Kota Tinggi, Johor Malaysia. E. faecalis was isolated by inoculated $1 \mathrm{~mL}$ of urine into a conical flask (250 mL) containing $25 \mathrm{~mL}$ of autoclaved nutrient broth, $10 \mathrm{~mL}$ of urea (40\%). The control was conducted without urine. For B. cereus, the medium consisted of $25 \mathrm{~mL}$ of autoclaved nutrient broth, $10 \mathrm{~mL}$ of $\mathrm{Mg} \mathrm{SO}_{4} .7 \mathrm{H}_{2} \mathrm{O}$ and $1 \mathrm{~mL}$ of acidic water, the control was carried out without acidic water. $\mathrm{pH}$ of the culture medium was adjusted before the sterilization to be more than $\mathrm{pH} 9$ by using $0.1 \mathrm{M}$ of $\mathrm{NaOH}$. The nitrogen gas was pumped from nitrogen gas cylinder throw pipe into the culture medium, which in role help on released oxygen. The dissolved oxygen (DO) was determined every day by oxygen meter to confirm that bacteria could survive in anaerobic condition. The flasks were incubated on the shaker with $125 \mathrm{rpm}$ for 16 d. These conditions were performed to stimulate the environmental conditions in the bio-concrete, and thus examine the bacterial potential to survive in the hard environment [23]. The concentration of bacterial cells were estimated by using spectrophotometry technique, $1 \mathrm{~mL}$ of the medium was diluted using sterilized distilled water to $10^{-5}$ and the optical density was measured by using a Nano-drop 2,000 spectrophotometer (Fisher Scientific). The ability of the bacterial strains to produce of urease enzymes was conducted by urease test according to Benson [24]. The ability to produce urease enzyme is the basic principle for the bio-concrete technique in this study.

In order to purify the bacterial strains, one $\mathrm{mL}$ of the culture medium was spread on Nutrient Agar (NA) medium according to Benson [24]. The plates were incubated at $30^{\circ} \mathrm{C}$ for $24 \mathrm{~h}$. One grown colony on NA was picked up and streaked on a new NA, and then incubated at $30^{\circ} \mathrm{C}$ for $24 \mathrm{~h}$. Thereafter, one pure colony was used for Gram staining and microscopic observation for identify the bacterial reaction for the gram staining and determine the bacterial cell morphology. Pure culture on NA media was sent to Universiti Sains Malaysia (USM) for molecular identification.

\subsection{Experimental Setup}

The chemical composition of Ordinary Portland Cement used in the current work is illustrated in Table S1. It was manufactured by Holcim Malaysia with all requirements defined by BS 197-1:2,000 [25]. The River sand used in this study as fine aggregate passing through $5 \mathrm{~mm}$ sieve, with the chemical composition presented in Table S2. The crushed stones with bulk density of $2,600 \mathrm{~kg} / \mathrm{m}^{3}$ were used as coarse aggregate in the size range of (12-20 mm). The water used for the concrete mixture was autoclaved to avoid the microbial contamination.

Factorial Complete Randomized Design (CRD) $(2 \times 7 \times 3 \times 3)$ in triplicate was used in this study to investigate the effects of selected bacterial strains in the improvement on the properties of concrete. Where: two (2) bacterial strains (E. faecalis and $B$. cereus) were isolated from urine and acid mire water from Sg Pelepah Kota Tinggi, Johor Malaysia, respectively. Each type was added to concrete mixture at the end to be the last step of mixing concrete as described by Juki et al [23]. Three (3) replacements $(1,3,5 \%)$ for water contents was carried out with E. faecalis 
Table 1. Mix Proportions of Bio-concrete with Different Percentages of $E$. faecalis and B. cereus Liquid Culture

\begin{tabular}{|c|c|c|c|c|c|c|c|}
\hline Mixture no. & M-1 & M-2 & M-3 & M-4 & M-5 & M-6 & M-7 \\
\hline Cement $\left(\mathrm{kg} / \mathrm{m}^{3}\right)$ & 420 & 420 & 420 & 420 & 420 & 420 & 420 \\
\hline Water $\left(\mathrm{L} / \mathrm{m}^{3}\right)$ & 210 & 207.9 & 203.7 & 199.5 & 207.9 & 203.7 & 199.5 \\
\hline E. faecalis $\left(\mathrm{L} / \mathrm{m}^{3}\right)$ & 0 & 2.1 & 6.3 & 10.5 & 0 & 0 & 0 \\
\hline E. faecalis (\%) & 0 & 1 & 3 & 5 & 0 & 0 & 0 \\
\hline B. cereus $\left(\mathrm{L} / \mathrm{m}^{3}\right)$ & 0 & 0 & 0 & 0 & 2.1 & 6.3 & 10.5 \\
\hline B. cereus (\%) & 0 & 0 & 0 & 0 & 1 & 3 & 5 \\
\hline Coarse aggregate $\left(\mathrm{kg} / \mathrm{m}^{3}\right)$ & 1,115 & 1,115 & 1,115 & 1,115 & 1,115 & 1,115 & 1,115 \\
\hline Fine aggregate $\left(\mathrm{kg} / \mathrm{m}^{3}\right)$ & 685 & 685 & 685 & 685 & 685 & 685 & 685 \\
\hline $\mathrm{W} / \mathrm{C}$ ratio & 0.54 & 0.54 & 0.54 & 0.54 & 0.54 & 0.54 & 0.54 \\
\hline
\end{tabular}

Note: M: denote mix number and percentage (\%) represent the replacement ratio of water by $E$. faecalis and $B$. cereus liquid culture by weight.

and three (3) replacements $(1,3,5 \%)$ was performed with $B$. cereus, while one concrete mixture (concrete without bacteria inoculation) was used as control making a total of (7) groups (Table 1). Three (3) tests were performed for each concrete including compressive strength, splitting tensile strength and water penetration were tested on three (3) curing periods (7, 14 and 28 d). Two different shapes of specimens were prepared namely, cube and cylinder following requirement of the tests. Cube specimens with size of $(150 \mathrm{~mm} \times 150 \mathrm{~mm} \times 150 \mathrm{~mm})$ were prepared for examining compressive strength and water penetration, while cylinders specimens with size ( $150 \mathrm{~mm} \times 300 \mathrm{~mm}$ length) were prepared for examining the splitting tensile strength. The control concrete mixture was designed according to Department of Environment (DoE) to achieve $30 \mathrm{MPa}$ of compressive strength at $28 \mathrm{~d}$ [26]. The water cement ratio (w/c) used was 0.54 for all mix proportion with and without bacteria.

\subsection{Testing of Specimens}

The compressive strength, splitting tensile strength and water penetration were tested on 7, 14 and $28 \mathrm{~d}$. The compressive strength test was performed according to BS 12390-3:2002 with $0.15 \mathrm{MPa} / \mathrm{s}$ loading rate of compressive strength test machine to obtain constant result. Water penetration test was conducted according to BS 1239-8:2000. In the water penetration test, the specimens were put under constant pressure of $5 \mathrm{kPa}$ for $72 \mathrm{~h}$. Then, the specimens were cut into half and measured the maximum depth of water penetration under the test area and the results were recorded in millimetre. Splitting tensile strength test was conducted according to BS 12390-6:2000.

The microstructure of bio-concrete was determined after 28 $\mathrm{d}$ of the curing period by the analyses using SEM and Energy Dispersive X-ray (EDX). Both SEM and EDX used DD ISO/TS 10798:2011: Nanotechnologies-Characterization as a guideline. Concrete samples for both SEM and EDX with length $(2 \mathrm{~cm})$ ware collected and dried at $60^{\circ} \mathrm{C}$ in oven for $24 \mathrm{~h}$ until constant conditions then send the samples to the lab to start analysis process. The analyses were performed in order to determine the bacteria precipitation of calcium and reduction in pores diameter in bio-concrete specimens compared to control.

\section{Results and Discussion}

\subsection{Bacterial Growth}

E. faecalis and B. cereus as identified based on $16 \mathrm{~S}$ rRNA sequences (Table S3 and S4) exhibited high potential to grow in the culture media with conditions similar to that available in the concrete environment. The growth curve of both strains is depicted in Fig. S1. The explanation here was performed based on the bacterial growth curve reported in previous study, where four phases for the bacterial growth included lag, log, stationary and death phase. As presented in the Fig. S1, the growth rate during the log phase was high, whereas the growth rate in the stationary phase was slow. Many of the studies have been reported that the growth rate of the bacterial cells during the stationary phase are less than the in the log phase [27]. The lag phase occurred in the first two days, where the optical density (OD) of the growth was increased with slow motion. The log phase started from $3^{\text {rd }}$ to $4^{\text {th }}$ days and the stationary phase started from $4^{\text {th }}$ to $12^{\text {th }}$ days, where the growth density increased from 0.03 to 0.61 and 0.02 to $0.56 \mathrm{~nm}$ for $E$. faecalis and B. cereus, respectively. The results revealed that $E$. faecalis exhibited more growth than $B$. cereus during the growth curve except for lag phase. The death phase started on $13^{\text {th }}$ day, the bacterial growth curve dropped from 0.61 to 0.58 and 0.57 to 0.55 NTU for $E$. faecalis and $B$. cereus, respectively. These findings are in line with those reported by Conlon [28] who indicated that the bacterial growth has four growth phases. In the lag phase the bacterial cells started to acclimatize on the new medium and then accelerate the growth in the exponential phase until reach the peak growth rate. The last phase is the death where the growth curve going down due to the deficiency in the nutrients and accumulation of secondary metabolic products, which affect negatively the bacterial growth.

\subsection{Compressive Strength}

Compressive strength of the concrete inoculated with different percentage of $E$. faecalis and B. cereus and in comparsion with the control is depicted in Fig. 1. The results revealed that the 


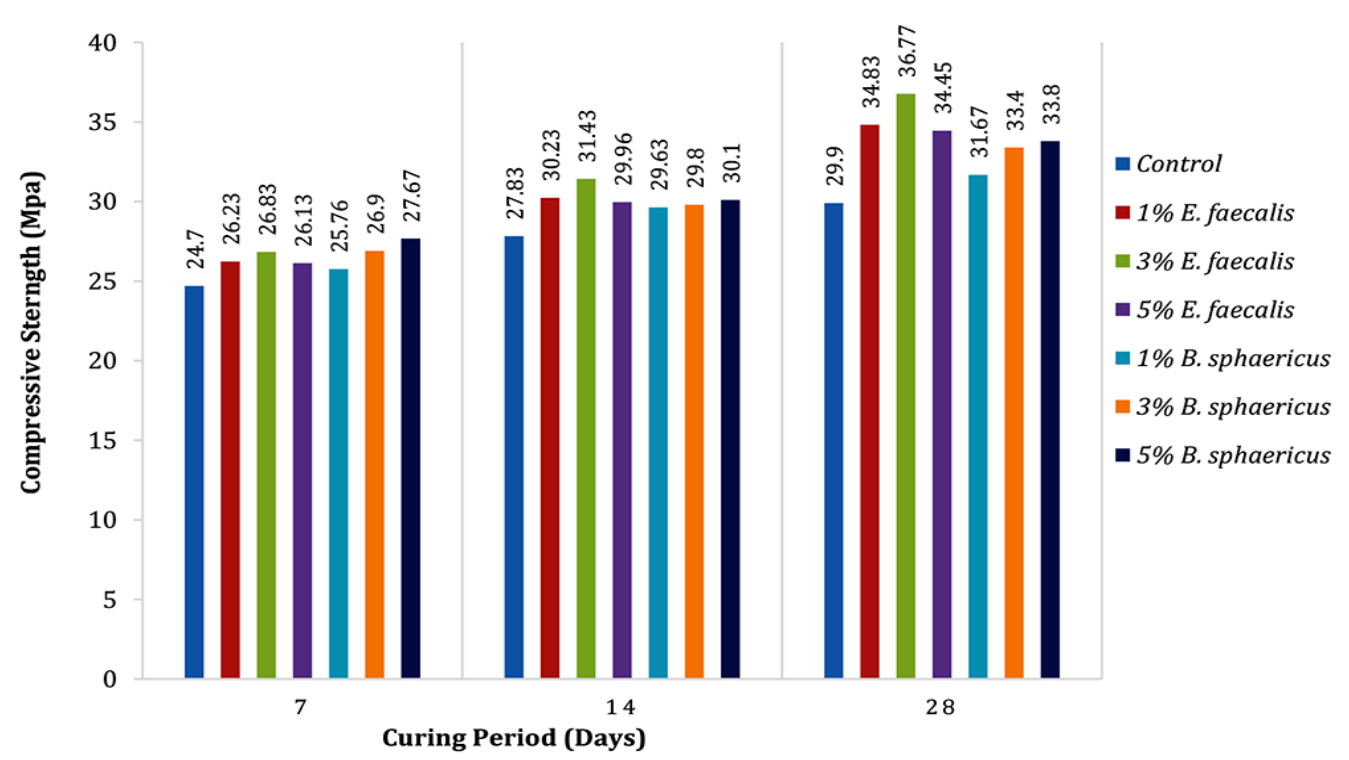

Fig. 1. Compressive strength for bio-concrete specimes with E. faecalis and B. cereus compare to control.

compressive strength of the concrete mixed with bacterial strains were more than in the control (No bacteria). The maximum compressive strength was recorded at $28 \mathrm{~d}$ of the curing period $(>$ $30 \mathrm{MPa}$ ). The compressive strength of bio-concrete has no significant differences after $7 \mathrm{~d}$ of the curing period. However, the maximum compressive strength (31.43 and 36.77\%) was recorded with $3 \%$ of $E$. faecalis on $14^{\text {th }}$ and $28^{\text {th }}$ day, respectively (Fig. 1). In contrast, the highest compressive strength (27.67 and 33.8\%) of the bio-concrete inoculated with $B$. cereus was observed with $5 \%$ on $7^{\text {th }}$ and $28^{\text {th }}$ days, respectively of the curing period. The increments of compressive strength of the specimens contained bacteria species were due to self-healing process of concrete pores via precipitation high amount of available Ca in cement on the bacteria cell wall, which in role react with bacteria cell resulting precipitate ions $\mathrm{Ca}^{2+}$ and $\mathrm{CO}_{3}^{2-}$ as $\mathrm{CaCO}_{3}$. However, increasing of $E$. faecalis ratio up to $5 \%$ in concrete caused a decrement on compressive strength compared to $3 \%$, whereas, the reduction on compressive strength may occurred due to the excessive bacteria activity with high concentration [17]

In a comparison between $E$. faecalis and $B$. cereus, it can be noted that $E$. faecalis was more efficient than $B$. cereus for the curing days considered. These findings might be due to the characteristics of E. faecalis which have more advantages compared to $B$. cereus. E. faecalis has the ability to grow at high $\mathrm{pH}(>$ $\mathrm{pH}$ 9) and with $6.5 \%$ of $\mathrm{NaCl}$, as well as the bacteria have high potential to produce urease enzyme which play an important role in precipitating high amount of calcium in the bio-concrete structure.

\subsection{Splitting Tensile Strength}

The influence of $E$. faecalis and $B$. cereus on splitting tensile strength in the bio-concrete is presented in Fig. 2. The results indicated that the inoculation of bacterial cell into the concrete enhanced the tensile strength compared to the control. The tensile strength increased significantly with the curing period up to 28 d. Among three inoculations of E. faecalis (1, 3 and 5\%), the maximum tensile strength recorded was at $3 \%$ (3.21 MPa). The increasing of bacterial replacement percentage to $5 \%$ affected, negatively, the tensile strength, which dropped to $3.04 \mathrm{MPa}$ after $28 \mathrm{~d}$. B. cereus exhibited less efficiency in the increasing of bio-concrete tensile strength in comparison to $E$. faecalis. It has enhanced the concrete tensile strength by $6.1 \%, 9.6 \%$ and $10.7 \%$ with 1 , 3 and 5\%, respectively compared to control specimens, respectively. The highest tensile strength $(3.11 \mathrm{MPa})$ was noted with $5 \%$ of the E. faecalis replacement percentage and after 28 d. The results indicated that E. faecalis and B. cereus play an important role in increase the strength of bio-concrete whether compressive or splitting tensile strength. However, splitting tensile strength considers as sensitive test of mechanical properties of concrete compared to compressive strength therefore, the increments of strength percentage using bio-concrete technology between both tests were different [29].

\subsection{Water Penetration}

The effect of bacterial inoculation of the water penetration of bio-concrete is depicted in Fig. 3. The results revealed that the water penetration of bio-concrete specimens reduced in comparison with the control. It can be noted that the water penetration decreased at all percentages of both types of bacteria. The maximum reduction in the water penetration was recorded with $3 \%$ of $E$. faecalis $(10.34 \%, 106.56 \mathrm{~mm})$ and $5 \%$ of $B$. cereus $(8.5 \%, 109.73 \mathrm{~mm})$ at $28 \mathrm{~d}$ compared to control (119.99 mm). These findings reflect role of bacterial inoculation in the reduction of water penetration in the bio-concrete, which represent one of the major problems affecting concrete sustainability. In addition, water penetration results confirmed the ability of that both bacterial strains used in the present study to reduce the water penetration is related to precipitation of the calcite on the surface of bacteria cells as a result of the production of urease enzyme, which in role make bio-concrete more sustain- 


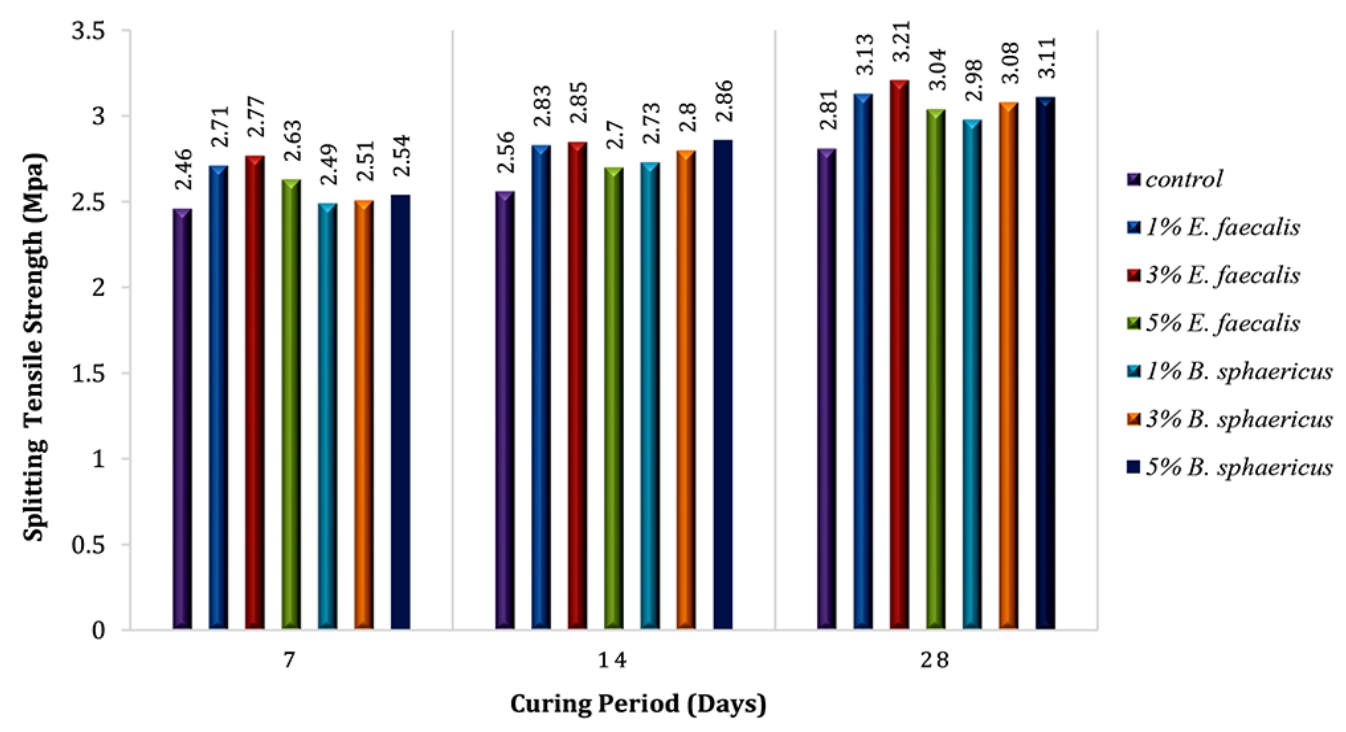

Fig. 2. Spliting tensile strength for bio-concrete specimes with E. faecalis and B. cereus compare to control.

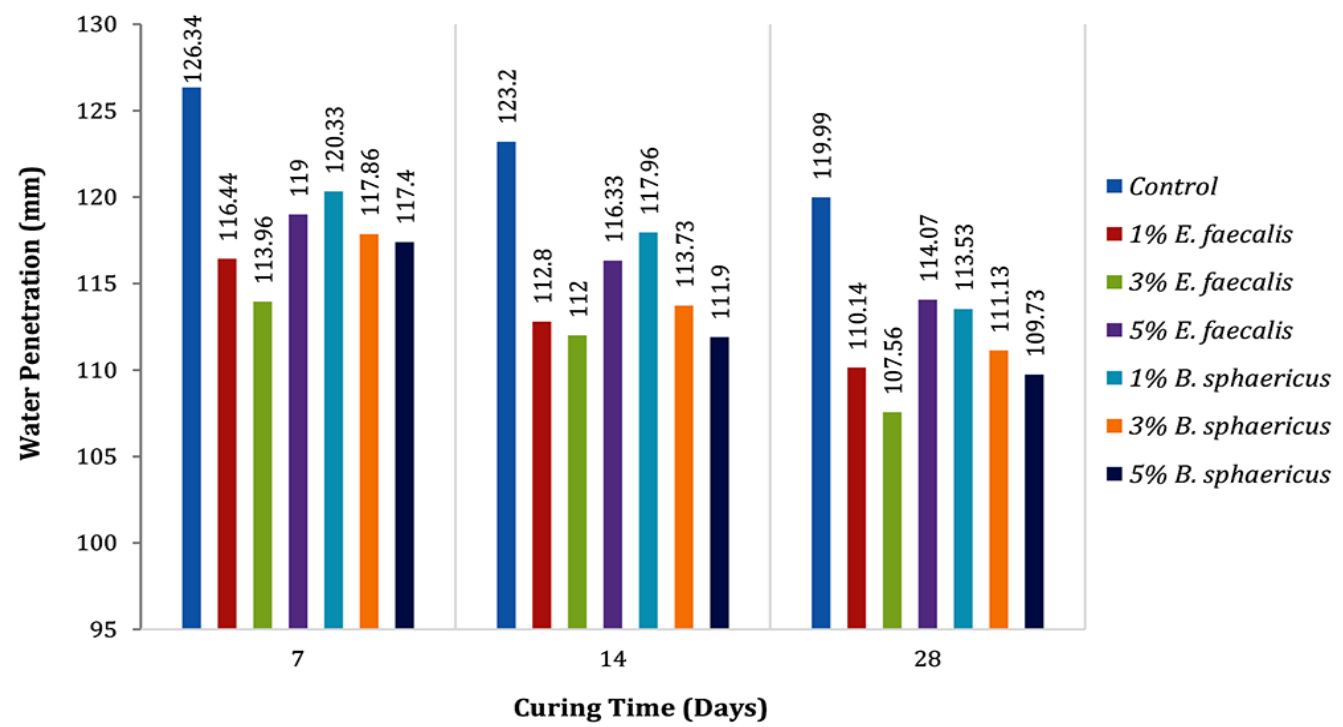

Fig. 3. Water penetration for bio-concrete specimes with E. faecalis and B. cereus compare to control.

able [30-33]. Whereas, concrete with high level of penetration allows gasses and water to permeate into the concrete, which causes deterioration in concrete materials and corrosion on steel bars. Increasing of concrete permeability leads to micro-cracks, which may progress to serious cracks when it's exposed to the load [33].

\subsection{Microstructure of Bio-Concrete}

The microstructure analysis was conducted to determine the pore size characteristic of the concrete [34] and investigate E. faecalis and $B$. cereus effects in healing the pores of bio-concrete specimens. The calcite precipitation and the pores in bio-concrete and control specimens are illustrated in Fig. 4. The SEM analysis of bio-concrete specimens inoculated with $E$. faecalis and B. cereus revealed presence of distinct calcite crystal and decrease in pores size (Fig. 4(b), (c)). Three different sizes of pores (maximum, average and minimum) were measured in each sample test of SEM to analysis the enhancement of healing process in concrete specimens. The results revealed that, at $28 \mathrm{~d}$ the average diameter of the pores size in bio-concrete specimens contain E. faecalis and B. cereus were $6.326 \mu \mathrm{m}$ and $6.532 \mu \mathrm{m}$, respectively in comparison to 13.153 $\mu \mathrm{m}$ of the control specimens. The high decrement of the pores size in bio-concrete specimens confirmed high calcium carbonate formed by the bacterial cells. The presence of calcite makes increased the strength and reduced the permeability of concrete. The improvement in bio-concrete properties incorporating E. faecalis and B. cereus can be easily understood from their distinct microstructure healing, which is in line with previous studies by $[8,35]$. 

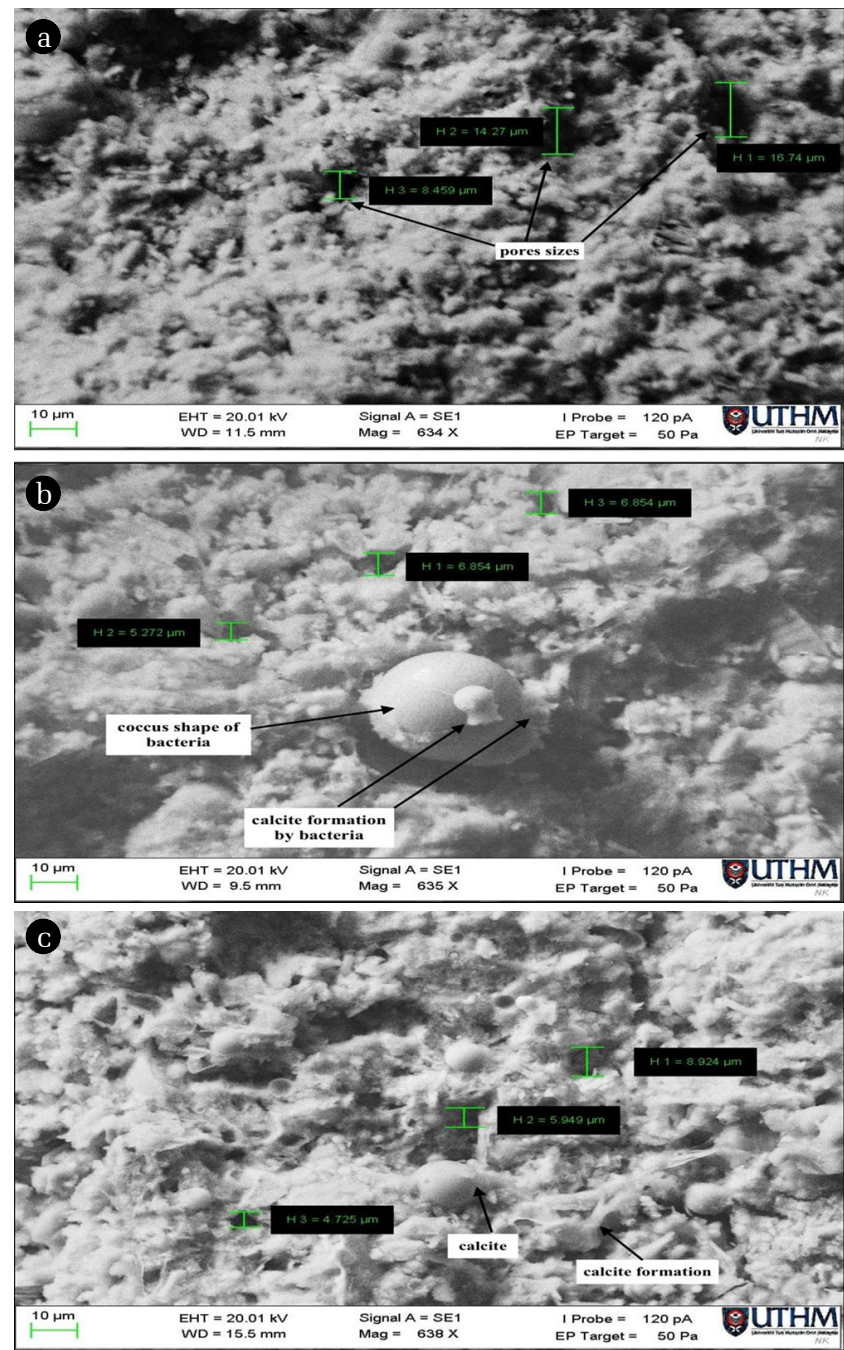

Fig. 4. Scanning electron microscope (SEM) of UB in concrete specimens with scale bar $10 \mu \mathrm{m}$. (a) For control specimen normal concrete (b) For bio-concrete specimen incorporated with $E$. faecalis (c) For bio-concrete specimen incorporated with $B$. cereus.

\subsection{Energy Dispersive X-ray (EDX)}

The chemical constituents of concrete specimens inoculated with $E$. faecalis and B. cereus were analysed by EDX. Based on the results presented in Fig. 5(a), it can be seen that the minerals present in control specimen included silica, calcium, aluminium and oxides. Fig. 5(b) and (c) showed the test results of bio-concrete samples with $E$. faecalis and $B$. cereus, respectively. The presence of high percentage calcium in bio-concrete samples is due to the role of bacterial cells in the precipitation of $\mathrm{CaCO}_{3}$. These observations are in agreement with decrement of pores size that discussed and showed in microstructure analysis (SEM) results as elucidate in Fig. 6. The results on SEM and EDX further confirmed that addition of $E$. faecalis and B. cereus in concrete resulted in significant improvement in concrete properties namely compressive strength, split tensile strength and water penetration.
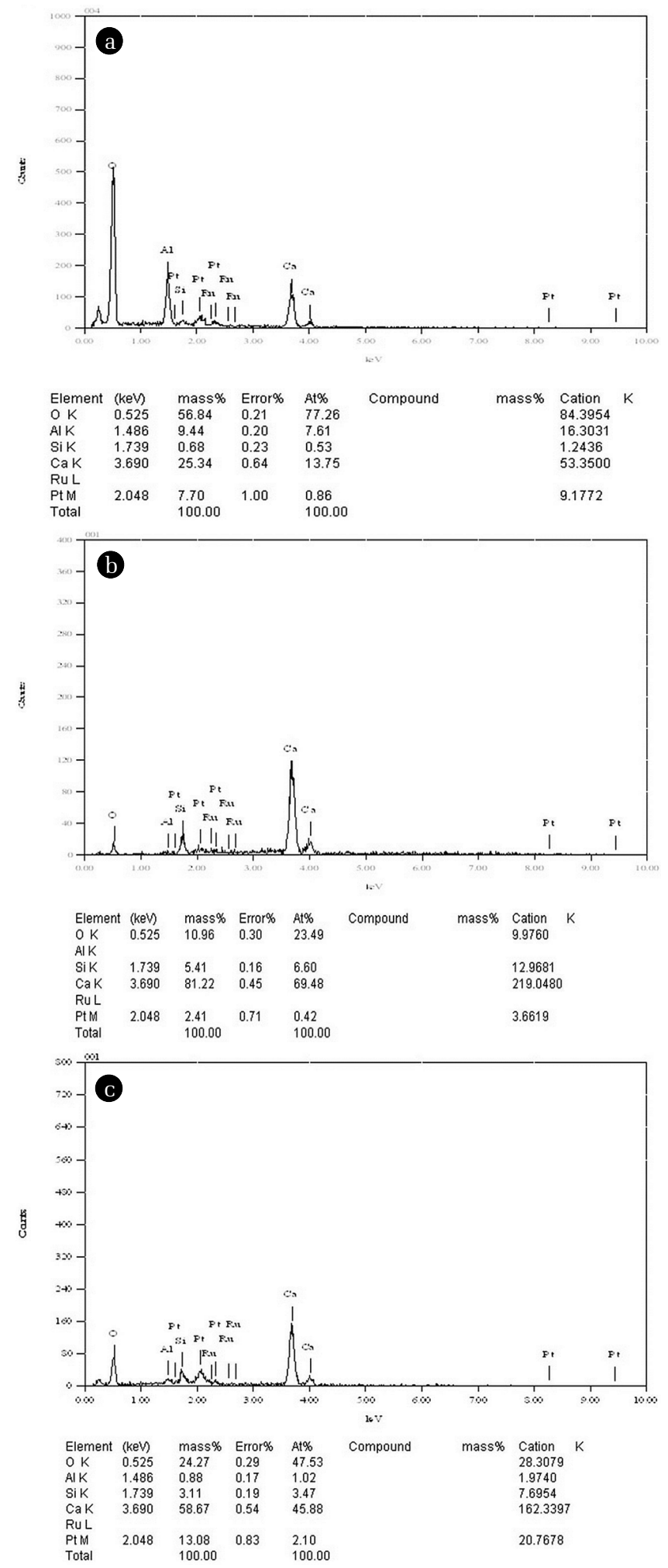

Fig. 5. Energy dispersive X-ray EDX for concrete specimens. (a) For control specimens (b) For bio-concrete specimen incorporated with $E$. faecalis (c) For bio-concrete specimen incorporated with B. cereus. 


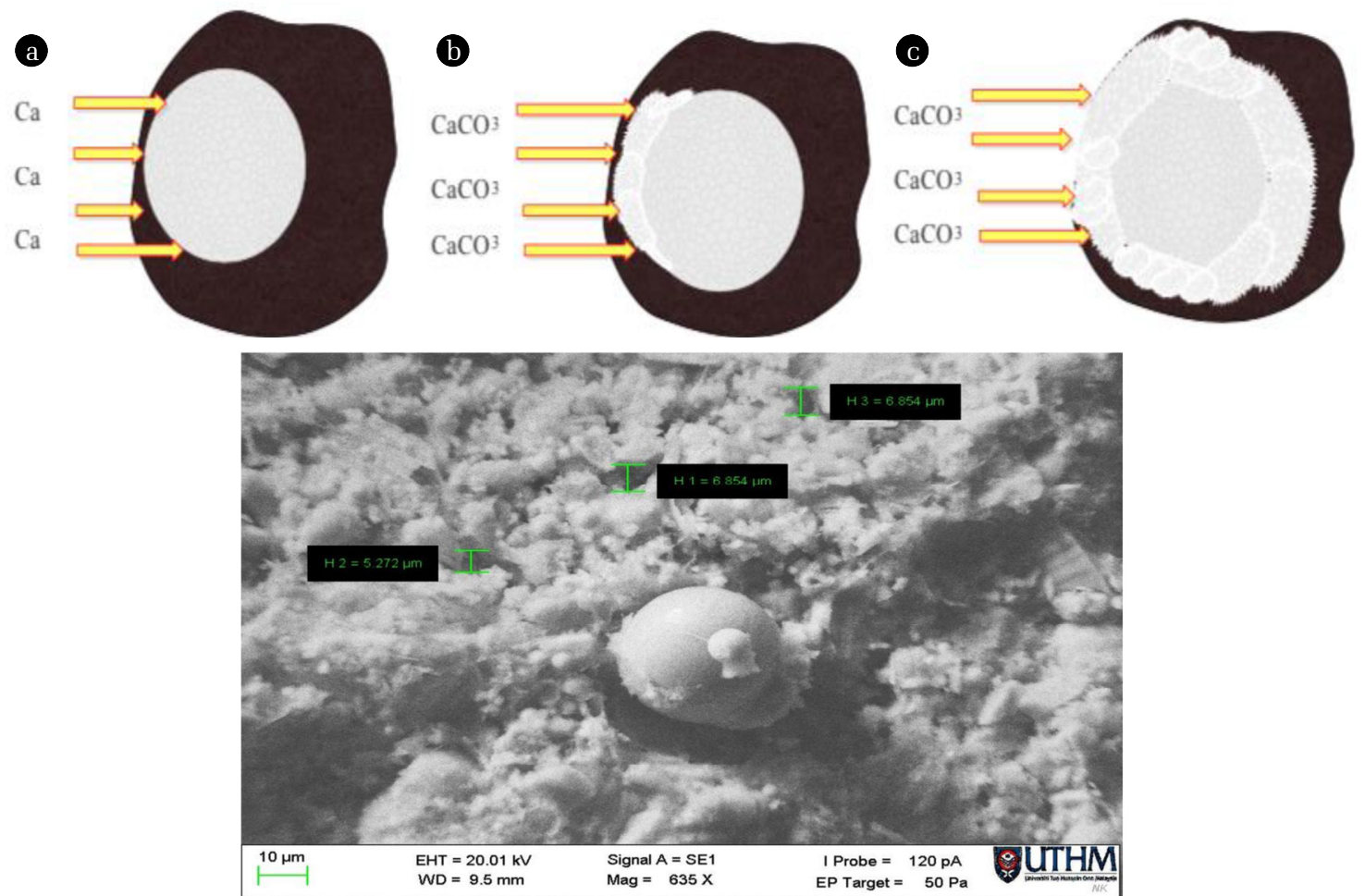

Fig. 6. Prevents the process of concrete pores self-healing via precipitation of calcium carbonate $\left(\mathrm{CaCO}_{3}\right)$ on bacteria cells wall. (a) Calcium (Ca) from cement attracts bacteria cell wall, (b) Precipitation of calcuim carbonate $\left(\mathrm{CaCO}_{3}\right)$ on the surface of bacteria, (c) Healing of concrete pore due to high precipitation of $\left(\mathrm{CaCO}_{3}\right)$.

\section{Conclusions}

It can be concluded that $E$. faecalis and $B$. cereus has the potential to be used in the bio-concrete in order to improve the concrete properties such as compressive strength, tensile strength and water penetration. The incorporation of both bacteria into concrete produces a higher amount of calcite in the samples of all curing periods and resulted self-healing of concrete pores up to $28 \mathrm{~d}$. Moreover, E. faecalis was more efficient than B. cereus. The characteristics of bio-concrete have improved with $3 \%$ of $E$. faecalis and $5 \%$ of $B$. cereus. Microstructure analysis using SEM and EDX confirmed that $E$. faecalis and $B$. cereus are capable precipitating calcium, which leads to increase in $\mathrm{CaCO}_{3}$.

\section{Acknowledgments}

This study was made possible through the grant by the Ministry of Education (MOE) under fundamental research Grant Scheme (FRGS Vot.1211) and supported by Universiti Tun Hussien Onn Malaysia (UTHM).

\section{References}

1. Abdel Gawwad HA, Mohamed SAE-A, Mohammed SA. Impact of magnesium chloride on the mechanical properties of innovative bio-mortar. Mater. Lett. 2016;178:39-43.

2. Vashisht R, Attri S, Sharma D, Shukla A, Goel G. Monitoring biocalcification potential of Lysinibacillus sp. isolated from alluvial soils for improved compressive strength of concrete. Microbiol. Res. 2018;207:226-231.

3. Jin S, Zhang J, Han S. Fractal analysis of relation between strength and pore structure of hardened mortar. Constr. Build. Mater. 2017;135:1-7.

4. Meddah MS, Al-Jabri K, Hago AW, Al-Hinai AS. Effect of granular fraction combinations on pervious concrete performance. Mater. Today Proc. 2017;4:9700-9704.

5. Yu Z, Ni C, Tang M, Shen X. Relationship between water permeability and pore structure of Portland cement paste blended with fly ash. Constr. Build. Mater. 2018;175:458-466.

6. Chopra D, Siddique R, Kunal. Strength, permeability and microstructure of self-compacting concrete containing rice husk ash. Biosyst. Eng. 2015;130:72-80.

7. Chandrappa AK, Biligiri KP. Comprehensive investigation of permeability characteristics of pervious concrete: A hydrodynamic approach. Constr. Build. Mater. 2016;123:627-637.

8. Xu J, Wang X. Self-healing of concrete cracks by use of bacteria-containing low alkali cementitious material. Constr. Build. Mater. 2018;167:1-14.

9. Wiktor V, Jonkers HM. Field performance of bacteria-based repair system: Pilot study in a parking garage. Case Stud. Constr. Mater. 2015;2:11-17. 
10. Wang J, Ersan YC, Boon N, De Belie N. Application of microorganisms in concrete: a promising sustainable strategy to improve concrete durability. Appl. Microbiol. Biotechnol. 2016;100:2993-3007.

11. Zhang J, Mai B, Cai T, et al. Optimization of a binary concrete crack self-healing system containing bacteria and oxygen. Materials 2017;10:116.

12. Kim HJ, Eom HJ, Park C, et al. Calcium carbonate precipitation by Bacillus and Sporosarcina strains isolated from concrete and analysis of the bacterial community of concrete. $J$. Microbiol. Biotechnol. 2016;26:540-548.

13. Power IM, Harrison AL, Dipple GM. Accelerating mineral carbonation using carbonic anhydrase. Environ. Sci. Technol. 2016;50:2610-2618.

14. Krajewska B. Urease-aided calcium carbonate mineralization for engineering applications: A review. J. Adv. Res. 2018;13:59-67.

15. Bundur ZB, Amiri A, Ersan YC, Boon N, De Belie N. Impact of air entraining admixtures on biogenic calcium carbonate precipitation and bacterial viability. Cement Concrete Res. 2017;98:44-49.

16. Mondal M, Khanra S, Tiwari ON, Gayen K, Halder GN. Role of carbonic anhydrase on the way to biological carbon capture through microalgae - A mini review. Environ. Prog. Sustain. Energy 2016;35:1605-1615.

17. Siddique R, Jameel A, Singh M, et al. Effect of bacteria on strength, permeation characteristics and micro-structure of silica fume concrete. Constr. Build. Mater. 2017;142:92-100.

18. Rajamma R, Senff L, Ribeiro MJ, et al. Biomass fly ash effect on fresh and hardened state properties of cement based materials. Compos. Part B Eng. 2015;77:1-9.

19. Wong LS. Microbial cementation of ureolytic bacteria from the genus Bacillus: A review of the bacterial application on cement-based materials for cleaner production. J. Clean. Prod. 2015;93:5-17.

20. Seifan M, Berenjian A. Application of microbially induced calcium carbonate precipitation in designing bio self-healing concrete. World J. Microbiol. Biotechnol. 2018;34:168.

21. Khaliq W, Ehsan MB. Crack healing in concrete using various bio influenced self-healing techniques. Constr. Build. Mater. 2016;102:349-357.

22. Jeong JH, Jo YS, Park CS, Kang CH, So JS. Biocementation of concrete pavements using microbially induced calcite precipitation. J. Microbial. Biotechnol. 2017;27:1331-1335.
23. Othman N, Irwan JM, Alshali AF, Anneza LH. Effect of ureolytic bacteria on compressive strength and water permeability on bio-concrete. In: Advances in civil, architectural, structural and constructional engineering: Proceedings of the international conference on civil, architectural, structural and constructional engineering. Busan: Dong-A Univ.; 2016. p. 335-338.

24. Benson JH. Microbiological applications: Laboratory manual in general microbiology. 7th ed. New York: WCB/McGraw-Hill; 2005.

25. British Standards Institution. Cement: Composition, specifications and conformity criteria for common cements. In: British Standards institution; 15 September 2000; London.

26. Department of Environment, Malaysia (DOE). Ministry of Science, Technology and the Environment. In: Environmental Quality Report. Kuala Lumpur; Environmental Quality Report; 1992. p. 266.

27. Marashdeh MQ, Gitalis R, Levesque C, Finer Y. Enterococcus faecalis hydrolyzes dental resin composites and adhesives. J. Endod. 2018;44:609-613.

28. Conlon BP, Rowe SE, Gandt AB, et al. Persister formation in Staphylococcus aureus is associated with ATP depletion. Nat. Microbiol. 2016;1:16051.

29. Bansal BK, Chouhan DS, Gupta T, Sharma RK. Behaviour of concrete utilizing metakaoline: A review. Eur. J. Adv. Eng. Technol. 2017;4:549-554.

30. Balam NH, Mostofinejad D, Eftekhar M. Effects of bacterial remediation on compressive strength, water absorption, and chloride permeability of lightweight aggregate concrete. Constr. Build. Mater. 2017;145:107-116.

31. Alonso MJC, Ortiz CEL, Perez SOG, et al. Improved strength and durability of concrete through metabolic activity of ureolytic bacteria. Environ. Sci. Pollut. Res. 2018;25:21451-21458.

32. Nosouhian F, Mostofinejad D, Hasheminejad H. Influence of biodeposition treatment on concrete durability in a sulphate environment. Biosyst. Eng. 2015;133:141-152.

33. Khaliq W, Ehsan MB. Crack healing in concrete using various bio influenced self-healing techniques. Constr. Build. Mater. 2016;102:349-357.

34. Jiang C, Fan K, Wu F, Chen D. Experimental study on the mechanical properties and microstructure of chopped basalt fibre reinforced concrete. Mater. Des. 2014;58:187-193.

35. Krishnapriya S, Venkatesh Babu DL, Prince Arulraj G. Isolation and identification of bacteria to improve the strength of concrete. Microbiol. Res. 2015;174:48-55. 